\title{
Uso de diopsídio em massas cerâmicas para grés sanitários
}

\section{(Use of diopside in ceramic masses for sanitary ware)}

\author{
R. H.L.Silva ${ }^{1,2 *}$, G. A. Neves ${ }^{2}$, H. C.Ferreira ${ }^{2}$, L. N. L. Santana ${ }^{2}$, A. C. V. Nóbrega ${ }^{3}$, R. R. Menezes ${ }^{2}$ \\ ${ }^{l}$ Instituto Federal de Pernambuco, Estr. Alto do Moura, s/n, Caruaru, PE, Brasil \\ ${ }^{2}$ Universidade Federal de Campina Grande, Centro de Ciências e Tecnologia, \\ Unidade Acadêmica de Engenharia de Materiais, Campina Grande, PB, Brasil \\ ${ }^{3}$ Universidade Federal de Pernambuco, Centro Acadêmico do Agreste, \\ Programa de Pós-Graduação em Engenharia Civil e Ambiental, Caruaru, PE, Brasil
}

\begin{abstract}
Resumo
Atualmente, há uma severa escassez de jazimentos de feldspato de boa qualidade. Por outro lado, o diopsídio vem se mostrando um fundente alternativo para a indústria cerâmica, mas ainda pouco estudado. Assim, este trabalho avaliou o efeito da substituição parcial do feldspato pelo diopsídio em formulações para grés sanitário. Substituiu-se de 2 a $20 \%$ da massa total de feldspato por diopsídio. As matérias-primas foram caracterizadas e as reologias das suspensões analisadas. Os corpos de prova foram conformados por colagem e queimados a 1160,1180 e $1200{ }^{\circ} \mathrm{C}$. As características reológicas não foram prejudicadas quando do uso de diopsídio, podendo-se substituir até $20 \%$ do feldspato por diopsídio. Com o emprego do diopsídio, houve formação de anortita e redução na temperatura de sinterização de 1200 para $1160{ }^{\circ} \mathrm{C}$. Nas massas com mais de $10 \%$ do feldspato substituído por diopsídio obtiveram-se maiores valores de resistência e menores de absorção de água e porosidade aparente.
\end{abstract}

Palavras-chave: cerâmica, diopsídio, fundente, feldspato, grés sanitário.

\begin{abstract}
There is a current severe shortage of good quality feldspar deposits. Nonetheless, diopside has been proved to be an alternative flux for the ceramic industry but still little studied. This work evaluated the effect of partial replacement of feldspar with diopside in formulations for sanitary ware. Replacement ratios ranged from 2 to $20 \%$ of the total mass of feldspar. Raw materials were characterized and rheology of suspensions was analyzed. The specimens were formed by slip casting and fired at 1160,1180 and $1200{ }^{\circ} \mathrm{C}$. Rheological characteristics were not impaired by using diopside, and up to $20 \%$ of feldspar could be replaced with diopside. Using diopside, it was noted anorthite formation and reduction of sintering temperature from 1200 to $1160{ }^{\circ} \mathrm{C}$. Masses with over $10 \%$ of diopside replacement resulted in higher values for strength and smaller ones for water absorption and apparent porosity.
\end{abstract}

Keywords: ceramic, diopside, feldspar, flux, sanitary ware.

\section{INTRODUÇÃO}

Massas para grés sanitário são compostas por matériasprimas com funções específicas no sistema, consistindo basicamente em uma combinação de argilas, quartzo e fundentes. Os fundentes favorecem a formação de fase líquida durante a queima e visam reduzir a temperatura de consolidação do corpo cerâmico, sendo indispensáveis para a obtenção de materiais cerâmicos com porosidades inferiores a $0,5 \%$, como porcelanas e grés sanitários de melhor qualidade. O fundente mais difundido na formulação de massas triaxiais para grés sanitário é o feldspato, representando cerca de $50 \%$ do total da massa seca empregada. No entanto, vem-se observando uma escassez das reservas de boa qualidade, demandando a necessidade

*ricardo.henrique@caruaru.ifpe.edu.br

(D) https://orcid.org/0000-0002-3106-9567 por busca de fontes alternativas que supram a necessidade do segmento tecnológico de grés, porcelanas e porcelanatos, frente à sua elevada significância econômica. Por outro lado, o diopsídio $\left(\mathrm{CaMgSi}_{2} \mathrm{O}_{6}\right)$, um silicato que pertence ao grupo dos piroxenos cálcicos, com estrutura caracterizada por cadeias de tetraedros de silício compartilhados e ligados através dos seus ápices às cadeias de extremidades de $\mathrm{CaO}_{8}$ [1], que ocorrem em rochas metamórficas, especialmente as de metamorfismo de contato sobre calcários [2], é uma matéria-prima conhecida para aplicações na tecnologia de vitrocerâmica [2] e alguns usos cerâmicos [1], devido ao seu ponto de fusão relativamente baixo e à baixa viscosidade da fase líquida associada à sua presença [2].

Assim, evidencia-se o potencial do diopsídio como material fundente para uso em formulações de grés sanitário, seja por sua fundência, seja pelo custo relativamente baixo em comparação com outros materiais com características ou potencial fundente [3]. Nesse sentido, estudos analisaram 
sua possível aplicação como fundente alternativo para indústria de grés sanitário em substituição ao feldspato [4-6], observando que é possível a utilização de diopsídio em substituição parcial de até $20 \%$ em massa de feldspato potássico adicionado a corpos cerâmicos para formulações de porcelanato. Outros autores evidenciaram que seu uso em massas cerâmicas pode promover a formação de anortita $[7,8]$, bem como seu baixo teor de ferro contribuiu para promover uma queima branca e obter corpos mais claros [9]. Adicionalmente, a utilização do diopsídio em substituição parcial ao feldspato em cerâmicas triaxiais diminuiu a temperatura de sinterização $[3,10]$, reduziu a porosidade em porcelanas e porcelanatos $[3,11]$ e aumentou a resistência à flexão nas formulações analisadas $[3,4,7]$.

Apesar das contribuições na literatura mundial quanto ao uso de diopsídio como matéria-prima fundente alternativa ao uso de feldspatos em formulações cerâmicas $[4,8,11]$, ainda há uma enorme carência de estudos e pesquisas que possibilitem uma plena compreensão da ação do diopsídio nos sistemas cerâmicos, particularmente nas formulações contendo elevado teor de fundentes, tal como as massas para uso em grés sanitários, e da sua interação com os fundentes quando usado em sua substituição parcial; sua influência na quantidade e viscosidade da fase líquida gerada na queima é fundamental no processo de consolidação e densificação do corpo cerâmico. Deste modo, o uso do diopsídio em formulações de grés sanitário que desenvolvem elevada quantidade de fase líquida durante a queima, e cuja resistência do corpo final depende da cristalização de grande parte dessa fase, deve ser plenamente dominada, uma vez que a presença do $\mathrm{Mg}$ e do Ca em grande quantidade, quando do uso do diopsídio, pode alterar a cinética de formação de fase líquida, a densificação e o processo de cristalização. Ademais, sua utilização em conjunto com o feldspato pode provocar alterações no comportamento de retração do material e alterar a curva de queima necessária ao adequado processo de consolidação do corpo cerâmico. Assim, este trabalho tem como objetivo avaliar o efeito da substituição parcial do feldspato pelo diopsídio em formulações para uso na fabricação de grés sanitário.

\section{MATERIAIS E MÉTODOS}

Matérias-primas: para o desenvolvimento desta pesquisa foram utilizadas as seguintes matérias-primas: caulim (oriundo de Gaibú-PE), ballclay (oriunda de Itambé$\mathrm{PB}$ ), quartzo (oriundo de Parelhas-RN), feldspato (oriundo de Parelhas-RN) e diopsídio (Arapiraca-AL). As amostras utilizadas neste estudo apresentaram granulometria inferior à peneira $A B N T n^{\circ} 200(0,074 \mathrm{~mm})$. As matérias-primas foram caracterizadas por: a) fluorescência de raios X (Shimadzu, EDX 720); b) difração de raios X (Shimadzu, XRD 6000), com radiação $\mathrm{CuK} \alpha(40 \mathrm{kV} / 30 \mathrm{~mA})$ e velocidade do goniômetro de $2 \%$ min e passo de $0,02^{\circ}$, com varredura de $5^{\circ}$ a $60^{\circ}$; e c) análise granulométrica por difração de laser (Cilas, 1064 LD).

Metodologia: foram formuladas composições com teores de diopsídio em substituição ao feldspato de $0 \%$ (M0), $2 \%$
(D2), 6\% (D6), 10\% (D10) e 20\% (D20), em relação à massa total de feldspato. O teor máximo de $20 \%$ foi determinado em função de observações de dados da literatura [4]. As formulações utilizadas encontram-se expostas na Tabela I. A massa de referência (M0) foi escolhida com base na formulação de uma massa comercial para a produção de grés sanitário e de acordo com orientações da literatura [12]. As matérias-primas (Tabela I) foram misturadas em moinho de bolas, via úmida, com $29 \%$ em massa de água, utilizando como defloculante silicato de sódio (Pernambuco Química), durante $1,5 \mathrm{~h}$, de modo a obter um resíduo entre 7 e $10 \%$ na peneira malha ABNT n $325(0,044 \mathrm{~mm})$. Após moagem, todas as massas cerâmicas foram peneiradas em malha ABNT $n^{\circ} 60(0,250 \mathrm{~mm})$, para a retirada de possíveis contaminações devido aos meios de moagem. Em seguida as dispersões foram submetidas à caracterização reológica, onde foram analisadas a curva de defloculação de todas as massas confeccionadas, tempo de secagem, velocidade de deposição, destacamento, umidade da película, relação $\alpha$ e o resíduo de moagem retido em malha ABNT n ${ }^{\circ} 325$ $(0,044 \mathrm{~mm})$. Para a determinação da curva de defloculação, a ação defloculante do silicato de sódio foi analisada pelo comportamento da viscosidade aparente da suspensão em função da adição de defloculante em volume $(\mathrm{mL})$ por $100 \mathrm{~g} /$ massa seca até atingir o ponto de viscosidade mínima aparente [13, 14]. A viscosidade foi determinada com um viscosímetro (Brookfield, RVT) com velocidade de rotação de $20 \mathrm{rpm}$ e spindel $\mathrm{n}^{\circ} 2$.

Tabela I - Composição das massas cerâmicas utilizadas (\% em massa).

[Table I - Composition of the ceramic masses used (wt\%).]

\begin{tabular}{ccc}
\hline Formulação* $^{*}$ & Feldspato & Diopsídio \\
\hline M0 & 47,2 & 0,0 \\
D2 & 46,3 & 0,9 \\
D6 & 44,4 & 2,8 \\
D10 & 42,5 & 4,7 \\
D20 & 37,8 & 9,4 \\
\hline
\end{tabular}

* - as frações de caulim, ballclay e quartzo foram mantidas constantes em $26,8 \%, 19,6 \%$ e 6,4\%, respectivamente, em todas as formulações.

Na determinação das características reológicas foram utilizadas suspensões que obtiveram máxima defloculação, determinada através da curva de defloculação descrita anteriormente, e então verificados a velocidade de deposição, o tempo de secagem, o destacamento da película do molde e a umidade da película. A velocidade de deposição (VD) é definida como a massa em gramas da película úmida da barbotina, depositada em 5 min em um estampo (molde) de gesso com forma de uma calota esférica de cerca de $200 \mathrm{~mL}$ de capacidade [12]. Na determinação de VD foi utilizado um estampo de gesso confeccionado em laboratório, mas com as mesmas características de porosidade de moldes usados comercialmente para produção de grés sanitários, com volume de $1000 \mathrm{~mL}$ e um tempo de permanência de 
2 min, após o qual o estampo de gesso foi drenado. As condições de $1000 \mathrm{~mL}$ e 2 min são indicadas na literatura [12] para massas industriais. Em seguida foi determinado o tempo de secagem (TS), que é o tempo necessário para que a superfície depositada no estampo, após drenagem, perca o brilho especular e fique fosca. A característica de destacamento da película foi avaliada por meio da estimativa da maior ou menor facilidade com que a película usada para medir VD e TS pôde ser destacada do estampo de gesso, conforme indicação da literatura [12]. A umidade da película foi determinada pelo teor percentual de água retida na película após se medir o TS, sendo expressa em percentagem em massa úmida na película. Posteriormente determinou-se o quociente entre os tempos (em segundos) para escoar, no viscosímetro de Mariotte, os volumes de 200 e $250 \mathrm{~mL}$ de barbotina, após agitação de 2 min, que é chamado de relação $\alpha$ [12]. Para o resíduo de moagem, a determinação seguiu o método utilizado pela indústria de louça sanitária onde foram preparadas as barbotinas. $\mathrm{O}$ método consiste em interromper a moagem da barbotina quando o teor de resíduo está na faixa de 7,0 a 9,0\% de retenção em peneira ABNT $n^{\circ} 325$ $(0,044 \mathrm{~mm})$. Estes valores foram obtidos com o volume de $100 \mathrm{~mL}$ em massa da barbotina. Em seguida, determinou-se a porcentagem de material retido na malha ABNT n $325(0,044$ $\mathrm{mm}$ ), expressando-o como resíduo de moagem.

$\mathrm{Na}$ sequência, foram conformados corpos de prova pelo processo de colagem em moldes de gesso de 60 × 20 x $5 \mathrm{~mm}$. As massas cerâmicas foram vertidas no molde, permanecendo no mesmo por um tempode aproximadamente $24 \mathrm{~h}$. Em seguida, os corpos de prova foram destacados e secos em estufa por $24 \mathrm{~h}$. Então, os corpos de prova foram submetidos ao processo de sinterização utilizando o seguinte ciclo de queima: $3^{\circ} \mathrm{C} / \mathrm{min}$ até $600{ }^{\circ} \mathrm{C}, 5^{\circ} \mathrm{C} / \mathrm{min}$ até $1000{ }^{\circ} \mathrm{C} \mathrm{e} 2{ }^{\circ} \mathrm{C} / \mathrm{min}$ até a temperatura de patamar, que foi de 1160,1180 e $1200{ }^{\circ} \mathrm{C}$. O tempo de patamar foi de $60 \mathrm{~min}$ na temperatura máxima de queima para simular os parâmetros de sinterização utilizados em $[15,16]$. Em seguida, o forno foi desligado para o resfriamento até a temperatura ambiente.

Visando avaliar o comportamento de queima e densificação das formulações, corpos de prova, após conformação e secagem, foram submetidos ao ensaio de dilatometria (Seratam, TMA Setsys 16/18). Após o processo de queima a 1160,1180 e $1200{ }^{\circ} \mathrm{C}$, os corpos de prova foram caracterizados por meio de: a) difração de raios X (Shimadzu,
XRD 6000 - conforme condições já mencionadas); e b) microscopia eletrônica de varredura (Shimadzu, SSX-550). Por fim foram executados ensaios de caracterização por meio dos ensaios físico-mecânicos de: a) absorção de água [17]; b) retração linear de secagem [18]; c) retração linear de queima [18]; d) porosidade aparente [19]; e e) resistência à flexão em três pontos [20], para determinação do módulo de ruptura à flexão (Shimadzu, Autograph AG-X, com célula de carga de $5 \mathrm{kN}$ e velocidade de aplicação de carga de $0,5 \mathrm{~mm} / \mathrm{min}$ ). A análise estatística foi realizada utilizando teste t para médias, após teste $\mathrm{F}$ para comparação de variância.

\section{RESULTADOS E DISCUSSÃO}

As composições químicas das matérias-primas utilizadas estão relacionadas na Tabela II. Observou-se que a argila ballclay e o caulim apresentaram percentuais de 50,8 e 48,3\% de óxido de silício $\left(\mathrm{SiO}_{2}\right)$, respectivamente. A sílica foi oriunda do quartzo livre presente nas amostras e dos argilominerais caulinita e ilita. Os teores de $\mathrm{Al}_{2} \mathrm{O}_{3}$ foram de $29,5 \%$ para a ballclay e de $38,2 \%$ para o caulim, e estão relacionados à camada octaédrica do argilomineral caulinita e da mica [21]. Os teores de $\mathrm{Fe}_{2} \mathrm{O}_{3}$ de $3,0 \%$ para a ballclay e de 2,3\% para o caulim foram considerados baixos, mas no limite do que é desejável para produção de cerâmica branca. Segundo [22], são desejáveis teores abaixo de $3 \%$ de $\mathrm{Fe}_{2} \mathrm{O}_{3}$ para a confecção de artefatos de coloração clara. A fundência fornecida pela presença do feldspato na massa cerâmica é oriunda dos óxidos alcalinos. É observado na Tabela II um percentual desses óxidos em torno de $10 \%\left(\mathrm{Na}_{2} \mathrm{O}+\mathrm{K}_{2} \mathrm{O}\right)$, típico de feldspatos usados para grés sanitários [2, 23], podendo-se classificá-lo como um feldspato potássico-sódico.

Considerando a composição química do diopsídio, tem-se que o diopsídio utilizado apresentou teores de $\mathrm{SiO}_{2}, \mathrm{CaO}$ e $\mathrm{MgO}$ inferiores aos teóricos para esse mineral, que são de $55,5 \%, 25,9 \%$ e $18,6 \%$, respectivamente [24]. Isso indicou a presença de outros minerais no material utilizado, que sejam, por exemplo, fontes de alumina e/ou que reduzam os teores totais de $\mathrm{CaO}$ e $\mathrm{MgO}$ no material final, haja visto o elevado teor de alumina no diopsídio utilizado e os menores valores de $\mathrm{CaO}$ e $\mathrm{MgO}$, comparativamente aos valores teóricos. Apesar dos valores de $\mathrm{CaO}$ e $\mathrm{MgO}$ serem inferiores aos teóricos, o teor de $\mathrm{CaO}$ e $\mathrm{MgO}$ superou 30\%, o que confere elevado poder fundente ao material utilizado

Tabela II - Composição química das matérias-primas (\% em massa).

[Table II - Chemical composition of raw materials (wt\%).]

\begin{tabular}{cccccccccccc}
\hline $\begin{array}{c}\text { Matéria- } \\
\text { prima }\end{array}$ & $\mathrm{SiO}_{2}$ & $\mathrm{Al}_{2} \mathrm{O}_{3}$ & $\mathrm{Fe}_{2} \mathrm{O}_{3}$ & $\mathrm{TiO}_{2}$ & $\mathrm{CaO}$ & $\mathrm{MgO}$ & $\mathrm{Na}_{2} \mathrm{O}$ & $\mathrm{K}_{2} \mathrm{O}$ & $\mathrm{P}_{2} \mathrm{O}_{5}$ & Outros & $\mathrm{PR}$ \\
\hline Ballclay & 50,8 & 29,5 & 3,0 & 0,6 & 0,2 & 1,2 & $\mathrm{ND}$ & 1,1 & $\mathrm{ND}$ & 0,5 & 13,1 \\
Caulim & 48,3 & 38,2 & 2,3 & 0,4 & 0,2 & 0,3 & $\mathrm{ND}$ & $\mathrm{ND}$ & $\mathrm{ND}$ & 0,2 & 10,1 \\
Quartzo & 96,8 & 2,3 & 0,1 & $\mathrm{ND}$ & 0,1 & $\mathrm{ND}$ & $\mathrm{ND}$ & 0,1 & $\mathrm{ND}$ & 0,3 & 0,3 \\
Feldspato & 72,3 & 16,2 & 0,2 & $\mathrm{ND}$ & 0,4 & $\mathrm{ND}$ & 3,2 & 6,8 & $\mathrm{ND}$ & 0,3 & 0,6 \\
Diopsídio & 52,9 & 7,1 & 1,2 & $\mathrm{ND}$ & 21,3 & 11,7 & $\mathrm{ND}$ & 0,9 & 2,6 & 0,6 & 1,7 \\
\hline ND - não detectado; $P R$ - perda ao rubro. & & & & & & & & &
\end{tabular}


como uma alternativa ao feldspato, particularmente em queima acima de $1170{ }^{\circ} \mathrm{C}$, temperatura de reação eutética no sistema $\mathrm{CaO}-\mathrm{Al}_{2} \mathrm{O}_{3}-\mathrm{SiO}_{2}$. Ademais, ao se considerar que na formulação utilizada ainda há a presença de elevados teores de $\mathrm{Na}_{2} \mathrm{O}$ e $\mathrm{K}_{2} \mathrm{O}$, acredita-se que há redução nesta temperatura eutética propiciando densificação significativa em temperaturas inferiores a $1170{ }^{\circ} \mathrm{C}$. Nesse sentido, estudos [7] já observaram que o diopsídio tem elevado potencial fundente quando da queima de formulações cerâmicas entre 900 e $1250{ }^{\circ} \mathrm{C}$, favorecendo a formação de fases líquidas e a dissolução dos óxidos de silício, alumínio, cálcio e magnésio. Por outro lado, o diopsídio apresentou um maior teor de óxido de ferro que o feldspato, o que poderia comprometer a cor da peça após queima, gerando colorações mais escuras, o que não é desejado na maioria dos casos que se busca produzir materiais porcelânicos e grés. Entretanto, embora o teor de óxido de ferro do diopsídio seja maior que o do feldspato $\left(1,27 \%\right.$ contra $\left.0,21 \%, \mathrm{Fe}_{2} \mathrm{O}_{3}\right)$, o ferro proveniente do diopsídio é incorporado na sua rede cristalina, substituindo o magnésio e, desta forma, é possível se obter composições com elevado índice de alvura em comparação com as placas cerâmicas convencionais, utilizando-se matérias-primas com teor de ferro um pouco maior [9]. Nesse sentido, estudos [7-9] evidenciam que corpos cerâmicos contendo diopsídio podem ser produzidos com tonalidades de branco semelhantes, ou até com maior alvura, que revestimentos de porcelanas convencionais, mesmo utilizando matérias-primas com teores de ferro superiores aos utilizados convencionalmente. Acredita-se que o maior teor de óxido de ferro do diopsídio, juntamente com as argilas utilizadas, que também apresentaram teores de óxido de ferro elevados, não compromete a coloração do material final, em virtude do teor total nas formulações estudadas não ultrapassar $2 \%$.

Observando os difratogramas de raios $\mathrm{X}$ do feldspato e diopsídio (Fig. 1), verificou-se que o feldspato apresentou picos característicos de sanidina - feldspato potássicosódico (JCPDS 10-0357), quartzo (JCPDS 46-1045) e mica muscovita (JCPDS 83-1803). Já o diopsídio apresentou as fases cristalinas: quartzo (JCPDS 46-1045), tremolita (JCPDS 85-0877), diopsídio (JCPDS 86-0932) e caulinita (JCPDS 140164). Diopsídios contendo traços de tremolita e quartzo são comuns na literatura $[25,26]$. Com base na difração de raios $\mathrm{X}$, observou-se que o menor teor de $\mathrm{CaO}$ e $\mathrm{MgO}$ no diopsídio analisado, comparativamente ao teórico, foi relacionado à presença de quartzo e de caulinita no material, o que, devese destacar, não compromete sua utilização como fundente na formulação analisada. Com relação às outras matériasprimas, tem-se que o caulim e a argila ballclay apresentaram caulinita (JCPDS 89-6538) e quartzo (JCPDS 46-1045) como fases cristalinas. A argila ballclay também apresentou picos característicos de esmectita (JCPDS 10-0357) e de microclina - feldspato potássico (JCPDS 19-0932). Esses resultados estão em consonância com resultados presentes na literatura voltados para a caracterização de caulins e argilas ballclay [27-29]. No que tange ao quartzo têm-se picos, como esperado, indicativos de quartzo alfa (JCPDS 46-1045).

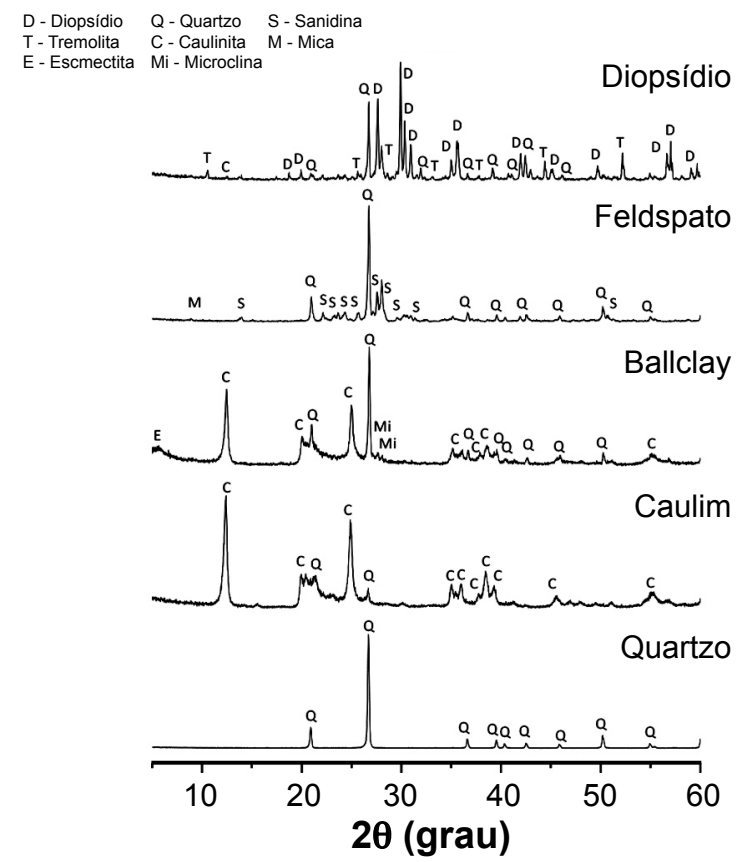

Figura 1: Difratogramas de raios $X$ das matérias-primas utilizadas. [Figure 1:X-ray diffraction patterns of used raw materials.]

Na Tabela III estão relacionados os valores das frações granulométricas acumuladas abaixo de $2 \mu \mathrm{m}$, entre 2 e 20 $\mu \mathrm{m}$ e superior a $20 \mu \mathrm{m}$, assim como os valores do diâmetro médio das partículas. O feldspato usado na formulação apresentou diâmetro médio de partículas $(27,0 \mu \mathrm{m})$ superior ao do diopsídio utilizado neste estudo $(12,3 \mu \mathrm{m})$. Além disso, verifica-se na Tabela III que o diopsídio apresentou maior quantidade de partículas finas, com maior fração acumulada nas faixas de diâmetro inferior a $2 \mu \mathrm{m}$ e de diâmetro entre $2 \mathrm{e}$ $20 \mu \mathrm{m}$. A maior finura do diopsídio utilizado se destacou pelo elevado teor de partículas com dimensões inferiores a $2 \mu \mathrm{m}$, o que indicou que a reatividade do diopsídio utilizado é muito elevada, o que pode favorecer os processos de densificação dos corpos produzidos em menores temperaturas, já que menores tamanhos de partícula e maiores áreas superficiais são fatores importantes para o aumento da reatividade entre as partículas, acelerando a cinética das reações e favorecendo

Tabela III - Frações granulométricas por tamanho de partículas das matérias-primas.

[Table III - Grain size fractions by particle size of raw materials.]

\begin{tabular}{ccccc}
\hline Amostra & $\begin{array}{c}\mathrm{x} \leq 2 \mu \mathrm{m} \\
(\%)\end{array}$ & $\begin{array}{c}2<\mathrm{x} \leq 20 \mu \mathrm{m} \\
(\%)\end{array}$ & $\begin{array}{c}\mathrm{x}>20 \mu \mathrm{m} \\
(\%)\end{array}$ & $\begin{array}{c}\text { Diâmetro } \\
\text { médio } \\
(\mu \mathrm{m})\end{array}$ \\
\hline Caulim & 44,4 & 55,6 & 0,0 & 3,3 \\
Ballclay & 37,8 & 56,1 & 6,1 & 5,6 \\
Quartzo & 18,8 & 58,9 & 22,3 & 12,2 \\
Feldspato & 6,1 & 37,8 & 56,1 & 27,0 \\
Diopsídio & 25,5 & 52,2 & 22,3 & 12,3 \\
\hline
\end{tabular}

$x$-fração acumulada. 
o processo de difusão que dita as transformações de fase. Entretanto, a diferença na distribuição granulométrica do diopsídio pode comprometer o empacotamento do sistema; nesse caso, mesmo com um alto teor de finos, pode ocorrer uma diminuição na densificação do sistema e/ou aumento na retração linear de queima em virtude do uso do diopsídio.

A Fig. 2 apresenta as curvas de defloculação das formulações analisadas. Observou-se que a adição do diopsídio provocou comportamentos distintos na curva de defloculação. Para teores de até $10 \%$ de substituição do diopsídio houve um aumento da viscosidade do sistema, provavelmente devido ao maior teor de finos quando da sua adição e/ou por uma contribuição no potencial zeta das partículas devido à presença do $\mathrm{Ca}$ e $\mathrm{Mg}$, presentes no diopsídio. Entretanto, essa segunda opção aparenta ser menos significativa que a primeira, em virtude do $\mathrm{Ca}$ e do $\mathrm{Mg}$ presentes no diopsídio estarem presentes na rede cristalina do material, diferentemente de quando presentes como íons trocáveis nas argilas. Assim, sua liberação no meio deve ser mais lenta, influenciando de forma pouco intensa o potencial zeta das partículas do meio, frente ao curto período de preparação da barbotina e determinação da viscosidade, comparativamente à influência que o maior teor de finos tem, considerando esse pequeno período. Outro comportamento foi observado quando da substituição de $20 \%$ do feldspato, verificando-se uma diminuição da

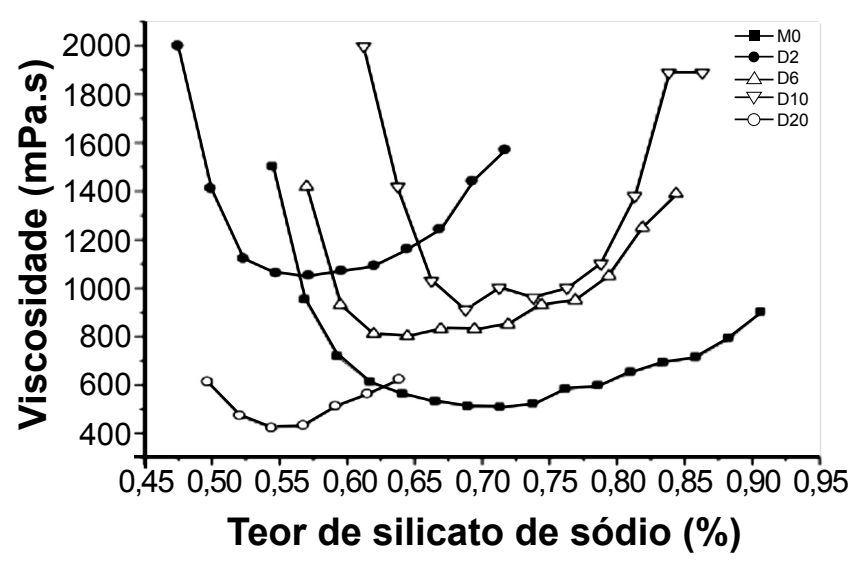

Figura 2: Curvas de defloculação das massas cerâmicas. [Figure 2: Deflocculation curves of ceramic masses.] viscosidade do sistema e um deslocamento do ponto de viscosidade mínima para menores teores de defloculante. Este comportamento foi constatado após diversas análises de viscosidade da composição D20, mas ainda não se tem uma explicação apropriada para tal fenômeno.

Conforme observado na Tabela IV, as formulações contendo diopsídio possuíram densidades da barbotina e relação $\alpha$ semelhantes aos valores da barbotina da formulação M0, utilizada como referência por ser usada na produção comercial de louças sanitárias. De forma geral, estes resultados foram em consonância com os apresentados em [12] para formulações visando aplicação na fabricação de grés sanitários. Para o resíduo de moagem, notou-se que as formulações utilizadas apresentaram resíduos em peneira ASTM \#325 semelhantes, indicando uma moagem similar para todos os sistemas. Com base nos valores obtidos para VD (velocidade de deposição) e tempo de secagem das formulações contendo diopsídio não foi possível visualizar a influência e/ou tendência do diopsídio no comportamento de deposição da formulação. Isso foi reforçado pelos valores semelhantes de relação $\alpha$ e umidade de película de todas as formulações analisadas. Deste modo, verificou-se que a adição do diopsídio em substituição parcial ao feldspato, na faixa de valores praticada neste estudo, não provocou alterações significativas nas características técnicas das dispersões produzidas utilizando o diopsídio.

A Fig. 3 apresenta as curvas de dilatometria das amostras M0, D6, D10 e D20. Nas curvas verificou-se a retração associada à desidroxilação dos argilominerais, com início em aproximadamente $520{ }^{\circ} \mathrm{C}$, a variação dimensional relacionada à expansão da transformação polimórfica do quartzo alfa em beta, em $573{ }^{\circ} \mathrm{C}$, a retração relacionada à formação da mulita, com início variando de 886 a $940{ }^{\circ} \mathrm{C}$, e a retração associada ao processo majoritário de densificação, com a formação da fase líquida e desenvolvimento de outras fases cristalinas. Verificou-se que a adição do diopsídio acelerou o processo de nucleação de mulita, provavelmente devido ao desenvolvimento precoce de fases líquidas e provocou a diminuição na temperatura de máxima retração (densificação), passando de $1187{ }^{\circ} \mathrm{C}$ na amostra padrão para $1170{ }^{\circ} \mathrm{C}$ na amostra com $20 \%$ de diopsídio. Isso, associado ao fato de haver um aumento na máxima taxa de retração com a adição do diopsídio, indicou que esse

Tabela IV - Características das formulações cerâmicas.

[Table IV - Characteristics of the ceramic formulations.]

\begin{tabular}{cccccc}
\hline Propriedade & M0 & D2 & D6 & D10 & D20 \\
\hline Massa específica $\left(\mathrm{g} / \mathrm{cm}^{3}\right)$ & 1,76 & 1,76 & 1,74 & 1,74 & 1,75 \\
Resíduo de moagem \#325 $(\%)$ & 8,0 & 7,1 & 8,8 & 8,3 & 9,0 \\
Velocidade de deposição $(\mathrm{g})$ & 56,5 & 64,7 & 56,8 & 64,7 & 57,9 \\
Tempo de secagem $(\mathrm{s})$ & 76,0 & 82,0 & 60,0 & 70,0 & 71,8 \\
Relação $\alpha$ & 0,6 & 0,6 & 0,6 & 0,6 & 0,6 \\
Umidade da película $(\%)$ & 26,8 & 26,9 & 27,0 & 29,0 & 27,5 \\
Destacamento & Bom & Bom & Bom & Bom & Bom \\
\hline
\end{tabular}


material acelerou o processo de densificação da formulação de grés sanitário analisada. Houve um aumento da máxima taxa com a adição do diopsídio, no entanto não se observou variação estatisticamente significativa ao se aumentar de 10 para $20 \%$ de diopsídio. Este comportamento é interessante porque indica que aumentando o teor de diopsídio, para até $20 \%$, é possível reduzir a temperatura ótima de sinterização, mas que não há um aumento exagerado na retração e consequentemente não há uma maior tendência/ possibilidade de alteração de forma da peça final quando do uso da máxima quantidade de diopsídio.

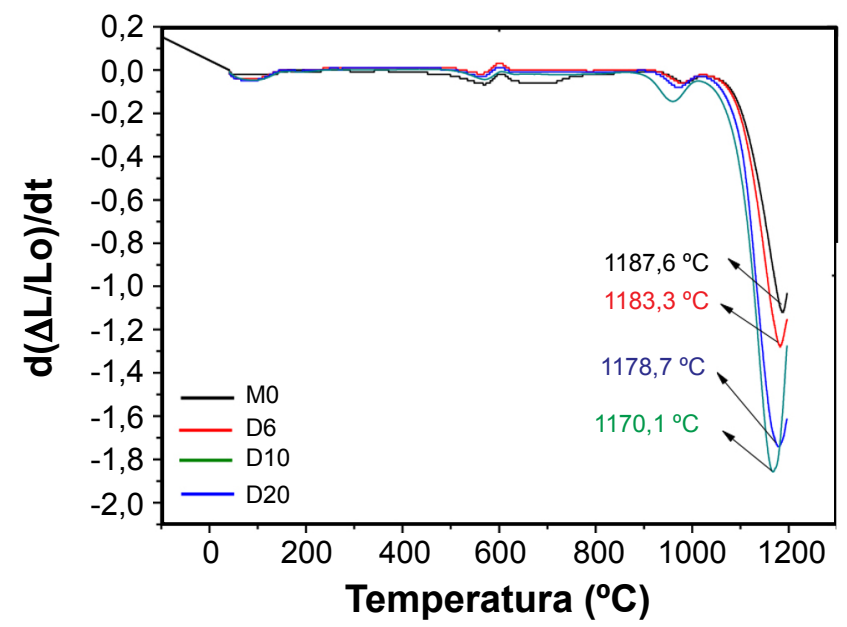

Figura 3: Curvas dilatométricas das massas cerâmicas.

[Figure 3: Dilatometric curves of ceramic masses.]

Os difratogramas de raios $\mathrm{X}$ das amostras após queima encontram-se expostos na Fig. 4. Observaram-se em todas as amostras as fases mineralógicas mulita (JCPDS 79-1276), quartzo (JCPDS 46-1045) e cristobalita (JCPDS 82-0512), com predominância de picos de mulita nos difratogramas. Não houve alteração significativa nas fases formadas após a sinterização nas temperaturas avaliadas (Fig. 4), no entanto verificou-se a formação de anortita (JCPDS 89-14620) nas amostras produzidas com massas contendo diopsídio. A fase anortita foi identificada nas amostras com incorporação de diopsídio para todas as temperaturas de sinterização, através da identificação de dois picos caracterizados pelas distâncias interplanares de 3,15 e 3,22 A. Assim, a substituição parcial do feldspato como fundente pelo diopsídio promoveu a formação da anortita $\left(\mathrm{CaAl}_{2} \mathrm{Si}_{2} \mathrm{O}_{8}\right)$, mas não de fases cristalinas contendo magnésio, como cordierita ou cordierita de ferro, corroborando os resultados da literatura $[7,8,10]$. A presença da fase anortita com a introdução do diopsídio foi relacionada ao elevado teor de cálcio de $21,32 \%$ nesse material (Tabela II), que na fase líquida rica em sílica e alumina propiciou a precipitação de anortita e corroborou os resultados da literatura [30,31]. Como não foi observada a presença de fases cristalinas associadas ao $\mathrm{Mg}$, como a cordierita $\left(\mathrm{Mg}_{2} \mathrm{Al}_{4} \mathrm{Si}_{5} \mathrm{O}_{18}\right)$ ou soluções sólidas do sistema cordierita-sekaninaita $\left[\left(\mathrm{Fe}^{++}, \mathrm{Mg}\right)_{2} \mathrm{Al}_{4} \mathrm{Si}_{5} \mathrm{O}_{18}\right]$, acredita-se que o $\mathrm{MgO}$ oriundo do diopsídio permaneceu após a queima dos corpos de prova dissolvido na fase vítrea do material.

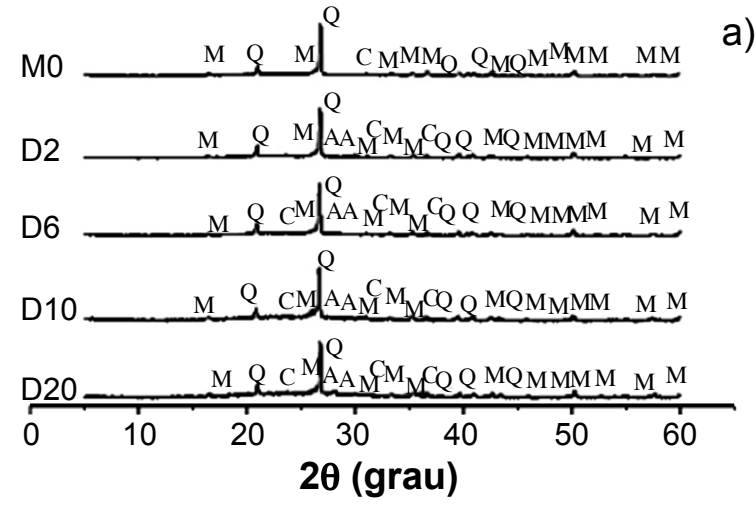

a)
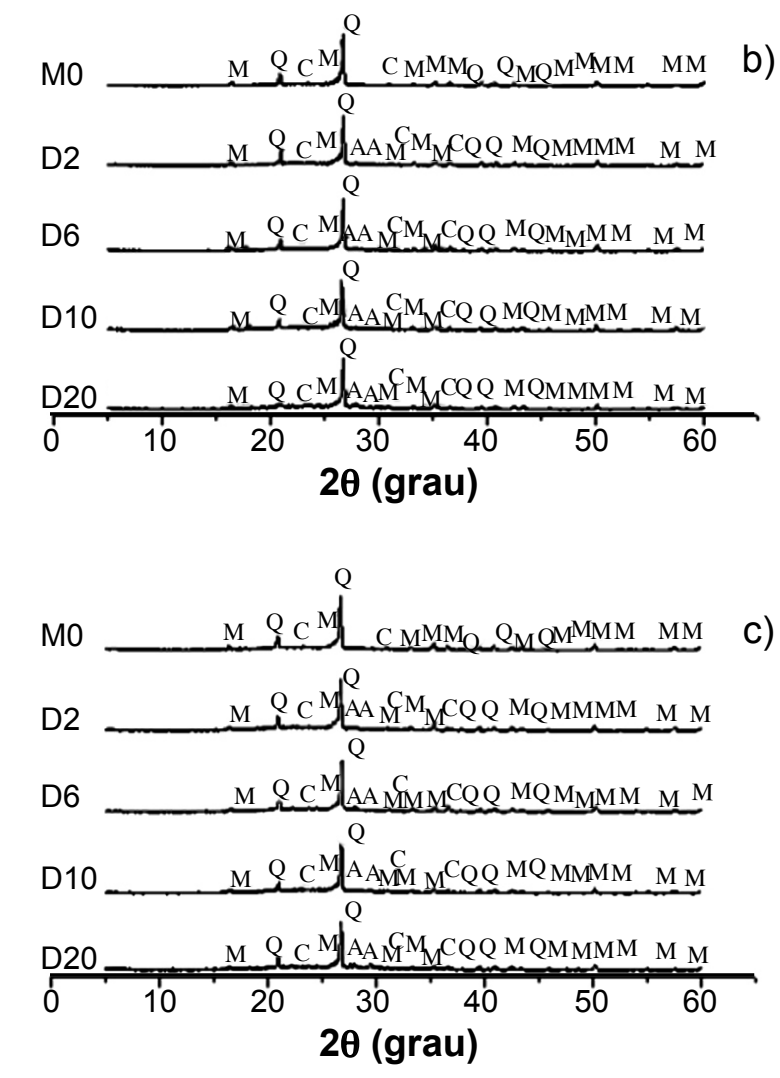

$M=$ Mulita $\quad Q=$ Quartzo $\quad C=$ Cristobalita $\quad A=$ Anortita

Figura 4: Difratogramas de raios X das massas cerâmicas em função da substituição parcial do feldspato pelo diopsídio nas temperaturas de sinterização de: a) $1160{ }^{\circ} \mathrm{C}$; b) $1180{ }^{\circ} \mathrm{C}$; e c) $1200{ }^{\circ} \mathrm{C}$.

[Figure 4: X-ray diffraction patterns of ceramic masses as a function of the partial substitution of feldspar by diopside at the sintering temperatures of: a) $1160^{\circ} \mathrm{C}$; b) $1180^{\circ} \mathrm{C}$; and c) $1200{ }^{\circ} \mathrm{C}$.]

Durante a queima houve a formação de fase líquida, a dissolução do diopsídio e a precipitação da anortita rica em $\mathrm{CaO}$, mas não houve a cristalização de fases contendo $\mathrm{MgO}$. Isso pode estar relacionado ao fato do teor total de $\mathrm{MgO}$ nas formulações analisadas, mesmo naquela com adição de $20 \%$ de diopsídio em substituição ao feldspato, ter sido inferior a 3\% (considerando a composição total das formulações), dificultando a precipitação de cordierita, e ao fato da queima ter sido efetuada a no máximo $1200{ }^{\circ} \mathrm{C}$. Nesse sentido, 
considerando o sistema $\mathrm{SiO}_{2}-\mathrm{Al}_{2} \mathrm{O}_{3}-\mathrm{MgO}$ e as composições das massas utilizadas, acredita-se que a formação de cordierita ocorreria apenas em temperaturas próximas a $1400{ }^{\circ} \mathrm{C}$. Esses
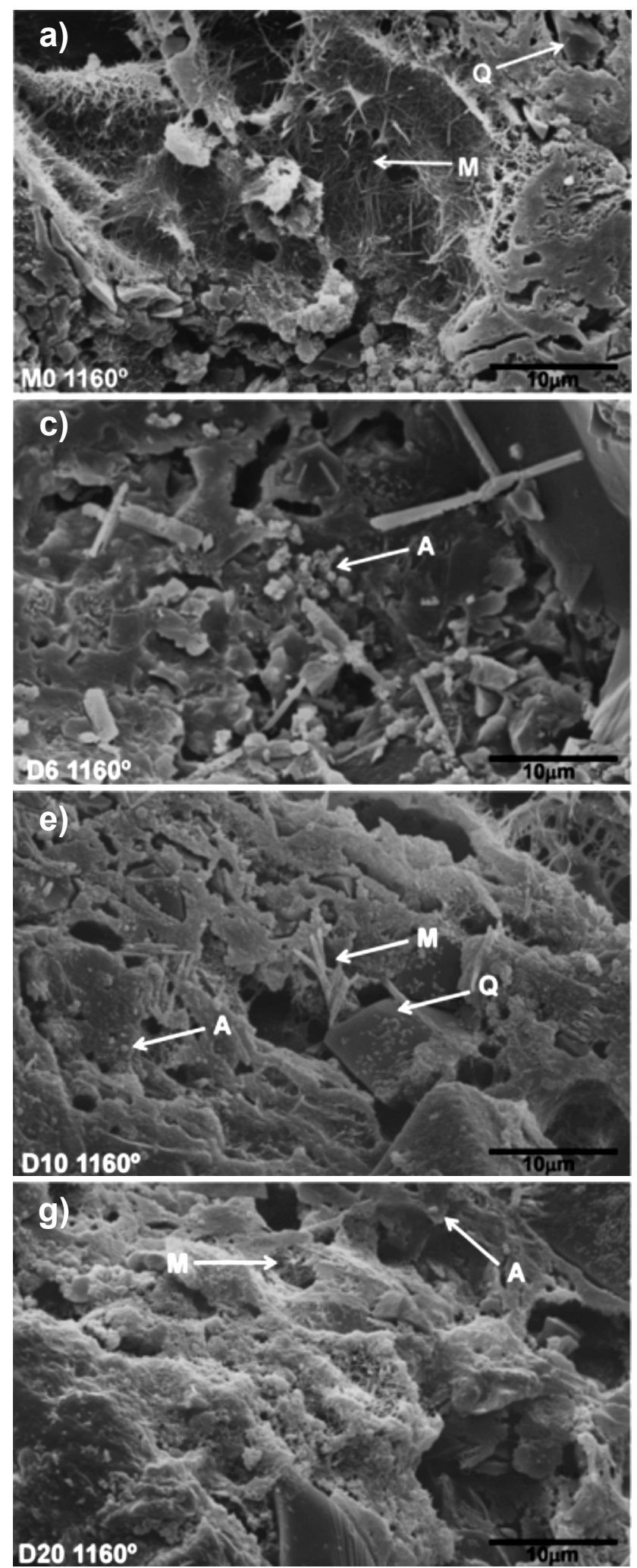

resultados estão em acordo com os resultados de [4], em que foi analisada a susbtituição do feldspato por diopsídio em massas cerâmicas e também não se observou o desenvolvimento de
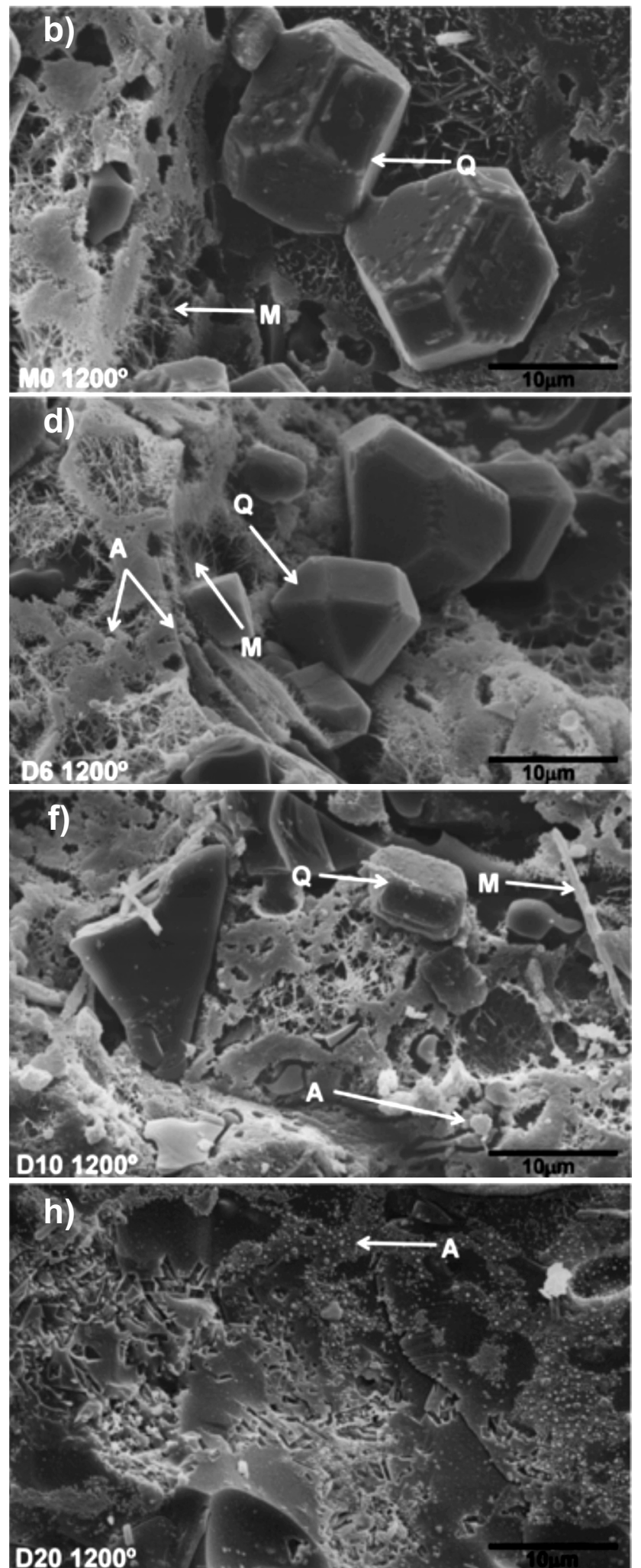

Figura 5: Micrografias de MEV das massas cerâmicas em função da substituição parcial do feldspato pelo diopsídio nas temperaturas de sinterização de 1160 e $1200{ }^{\circ} \mathrm{C}$ (M - mulita, Q - quartzo, A - anortita).

[Figure 5: SEM micrographs of ceramic masses as a function of the partial substitution offeldspar by diopside at the sintering temperatures of 1160 and $1200{ }^{\circ} \mathrm{C}(\mathrm{M}$ - mullite, $Q$ - quartz, $A$ - anorthite $\left.).\right]$ 
fases cristalinas relacionadas à presença do $\mathrm{MgO}$.

$\mathrm{Na}$ Fig. 5 estão apresentadas as micrografias (de superfícies de fratura) obtidas por microscopia eletrônica de varredura (MEV) das formulações M0, D6, D10 e D20 após tratamento térmico a 1160 e $1200{ }^{\circ} \mathrm{C}$. Pôde-se observar que o tratamento térmico proporcionou uma microestrutura caracterizada pela presença de pequenas agulhas de cristais de mulita, grãos de quartzo e, nas amostras contendo diopsídio, principalmente na D20, cristais esferoidais relacionados à anortita. Observou-se que nas amostras contendo diopsídio, D6 e D10, houve o desenvolvimento de cristais de mulita mais colunares e não tão aciculares, indicando uma cinética de crescimento desse material diferente da que ocorreu na amostra M0.

Na Fig. 6 constam os valores médios obtidos para a retração linear de secagem e retração linear de queima das formulações estudadas. Observou-se queas amostras contento diopsídio não apresentaram diferenças estatisticamente significativas na retração de secagem (teste t, valor $\mathrm{p}>0,05$ ). No entanto, foi observado que houve um aumento da retração linear de secagem em relação à massa padrão (teste $\mathrm{t}$, valor $\mathrm{p}<0,05)$, o que pode estar associado a uma diminuição do empacotamento do sistema quando da adição do diopsídio, tendo em vista que o mesmo possuiu uma distribuição de tamanho de partículas diferente do feldspato, com um menor tamanho médio de partículas e uma maior fração de finos que o feldspato. Essas alterações de empacotamento com a adição do diopsídio foram detectadas com a análise de parâmetros reológicos, que refletiram na maior variação dimensional dos corpos após secagem. Todas as amostras analisadas apresentaram retração linear de queima inferior a $11 \%$, estando de acordo com os dados da literatura [3234] para porcelanas com elevada quantidade de fase vítrea ou grés sanitários, que apresentam valores de retração linear de queima em torno de $10 \%$. A massa padrão apresentou o comportamento esperado de aumento da retração linear com o aumento da temperatura de queima (teste t, valor $\mathrm{p}$ $<0,05)$. Já as amostras contendo diopsídio apresentaram dois comportamentos. $\mathrm{O}$ primeiro foi relacionado às amostras D2 e D6, que apresentaram um aumento da retração de queima com a temperatura, no entanto esse comportamento diferiu da massa padrão, porque não houve diferença estatisticamente significativa nas suas retrações após queima a 1180 e $1200{ }^{\circ} \mathrm{C}$ (teste $\mathrm{t}$, valor $\mathrm{p}>0,05$ ), tanto na $\mathrm{D} 2$ como na D6, diferentemente do que ocorreu com a massa padrão, que possuiu um aumento na retração quando foi queimada a $1200{ }^{\circ} \mathrm{C}$. O segundo comportamento foi relacionado às amostras D10 e D20, que apresentaram uma diminuição na retração com o aumento da temperatura de queima para $1200{ }^{\circ} \mathrm{C}$ (teste $\mathrm{t}$, valor $\mathrm{p}<0,05$ ), mas que não apresentaram diferença estatisticamente significativa na retração após queima a 1160 e $1180{ }^{\circ} \mathrm{C}$ (teste $\mathrm{t}$, valor $\mathrm{p}>0,05$ ). Esse comportamento vem ao encontro do observado na dilatometria, onde se verificou que as amostras D10 e D20 apresentaram uma taxa de retração bem maior que a amostra padrão e a amostra D6, como também uma redução na temperatura de máxima taxa de retração. Isso indicou que as amostras com 10 e $20 \%$ de adição de diopsídio apresentaram sua máxima densificação em temperaturas mais baixas, em torno de 1160 e $1180{ }^{\circ} \mathrm{C}$ e que o aumento da temperatura (para $1200{ }^{\circ} \mathrm{C}$ ) pode ter provocado dois fenômenos que conduziram à diminuição na retração/densificação do corpo cerâmico: um aumento da viscosidade da fase líquida, que diminuiu a cinética de retração/densificação, relacionado ao fenômeno de cristalização e aumento da quantidade de fases cristalinas (mulita e anortita) e à dissolução de quartzo na fase líquida; e a um aumento na porosidade e/ ou tamanho dos poros fechados do material, seja através do fenômeno de Ostwald ripening para coalescência de poros ou pelo processo de expansão dos poros devido ao aumento de pressão dos gases presentes no seu interior. Por outro lado as amostras D2 e D6 aumentaram a retração e, possivelmente, a densificação quando a temperatura aumentou para $1180{ }^{\circ} \mathrm{C}$ e não aumentaram mais a retração quando do aumento para $1200{ }^{\circ} \mathrm{C}$, o que está em consonância com a temperatura de máxima taxa de retração determinada para a amostra D6, de $1182{ }^{\circ} \mathrm{C}$ (Fig. 3), e indicou que as amostras com menor teor de diopsídio requerem temperatura de queima inferior a $1200{ }^{\circ} \mathrm{C}$, mas superior a $1160{ }^{\circ} \mathrm{C}$ para atingir sua máxima densificação. Comparativamente à amostra padrão, teve-se de forma geral que as amostras contendo diopsídio apresentaram maiores retrações de queima (teste $t$, valor $\mathrm{p}<0,05$ ), nas
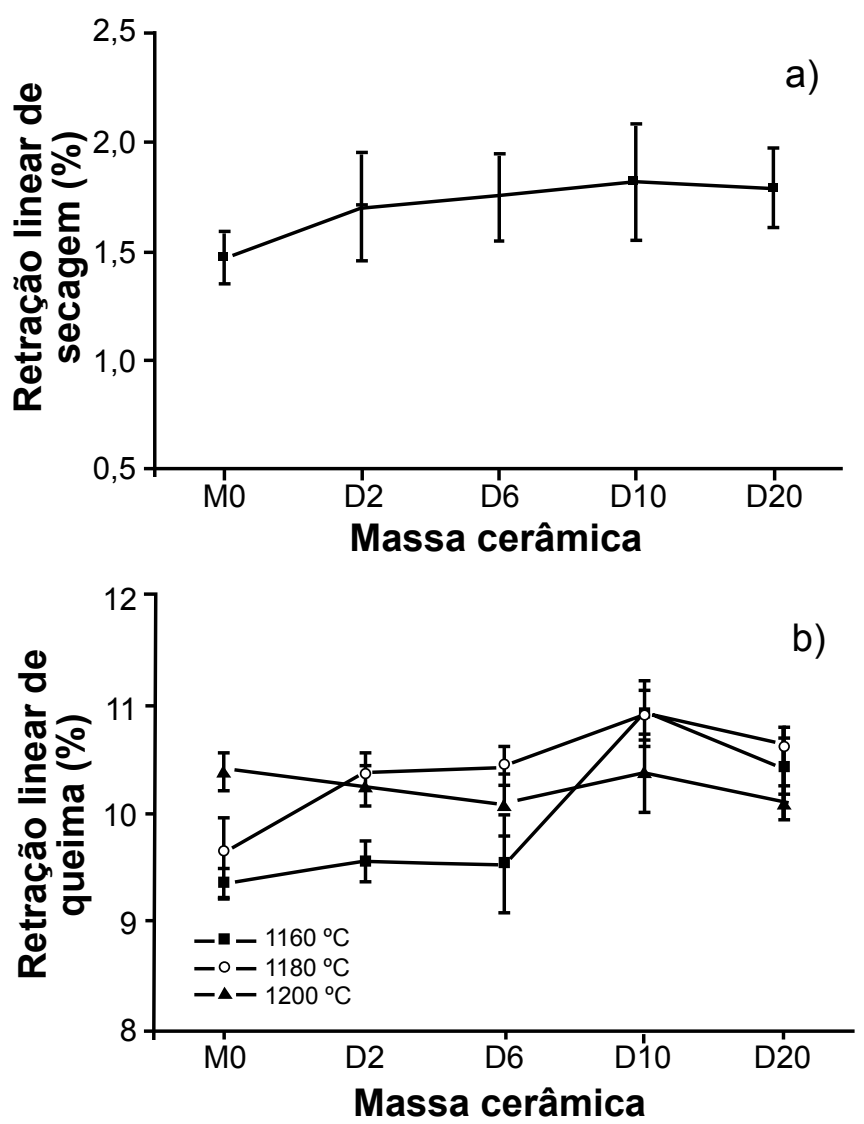

Figura 6: Retração linear de secagem (a) e retração linear de queima (b).

[Figure 6: Linear drying shrinkage(a) and linear firing shrinkage (b).] 
temperaturas de 1160 e $1180{ }^{\circ} \mathrm{C}$, em virtude de suas maiores taxas de retração (Fig. 3) em temperaturas mais baixas. No entanto, não houve diferença estatisticamente significativa entre o valor da maior retração de queima da amostra de referência (atingido a $1200{ }^{\circ} \mathrm{C}$ ) e as maiores retrações de queima das amostras contendo diopsídio (atingidas a 1160 e $1180{ }^{\circ} \mathrm{C}$ ), indicando que o corpo queimado produzido com as formulações contendo diopsídio não teve alterações dimensionais significativas comparativamente aos corpos produzidos sem diopsídio, considerando-se as temperaturas ótimas de queima de cada composição e o adequado ajuste do ciclo de queima para as formulações contendo diopsídio.

A Fig. 7 apresenta os valores de absorção de água e porosidade aparente das amostras analisadas. Verificouse, em todas as amostras, um decréscimo dos valores de absorção de água e porosidade aparente com o aumento da temperatura de queima. No entanto esses decréscimos foram muito mais intensos na amostra padrão, haja vista a maior retração e densificação das amostras contendo diopsídio já nas temperaturas de 1160 e $1180{ }^{\circ} \mathrm{C}$. Estudos [10] observaram elevado desenvolvimento de fase líquida em amostras de porcelana contendo $10 \%$ de diopsídio, mesmo após queima em temperatura significativamente inferior $\left(\Delta \mathrm{T}>50^{\circ} \mathrm{C}\right)$ às temperaturas de queima da amostra de referência, apresentando por conseguinte, tal como neste trabalho, valores de absorção de água inferiores a $0,5 \% \mathrm{em}$ temperaturas entre 1150 e $1170{ }^{\circ} \mathrm{C}$. Outros estudos, que abordaram a substituição do feldspato por diopsídio [3, 4], também constataram menores temperaturas para se atingir absorções de água inferiores a $0,5 \%$, comparativamente às suas formulações de referência. Deste modo, verificou-se que o comportamento de redução da absorção de água e porosidade aparente em massas de grés sanitário contendo diopsídio, frente às amostras convencionais, sem diopsídio, constatado nesta pesquisa, é inerente a adição do diopsídio e associado ao seu elevado poder fundente. Por outro lado, neste pesquisa o diopsídio também apresentou uma fração de finos (partículas $<2 \mu \mathrm{m}$ ) significativamente elevada e bem maior que a fração de finos do feldspato, o que também pode ter contribuído para esse comportamento, além do seu poder fundente. O menor tamanho de partícula do diopsídio pode ter facilitado no processo de densificação, seja favorecendo a formação de fase líquida, seja aumentando a cinética do processo de difusão em estado sólido ou fazendo com que as a partículas fossem mais susceptíveis à tensão capilar da fase líquida e consequentemente se arranjando de forma mais significativa durante a sinterização, o que favorece a densificação, aumenta a retração e diminuiu a absorção de água.

No que tange ao comportamento da absorção de água e porosidade aparente das amostras de diopsídio em função da temperatura de queima, teve-se um comportamento semelhante ao observado para a retração linear de queima. Observou-se que as amostras D2 e D6 apresentaram os mesmos valores de absorção e porosidade para as temperaturas de queima de 1180 e $1200{ }^{\circ} \mathrm{C}$ (teste t, valor $\mathrm{p}>0,05)$, enquanto que para as amostras D10 e D20 não
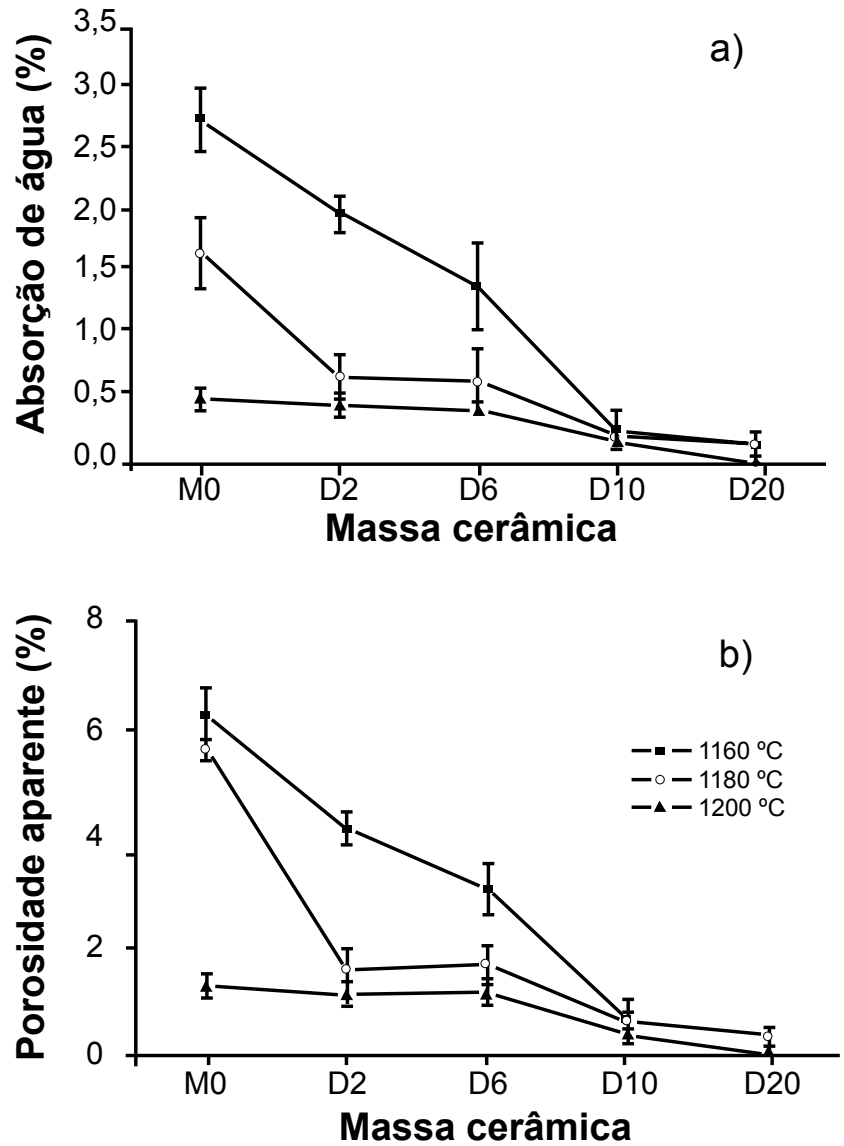

Figura 7: Absorção de água (a) e porosidade aparente (b) em função da substituição parcial do feldspato pelo diopsídio nas temperaturas de sinterização de 1160,1180 e $1200{ }^{\circ} \mathrm{C}$.

[Figure 7: Water absorption (a) and apparent porosity (b) as a function of the partial substitution of feldspar by diopside at the sintering temperatures of 1160,1180 , and $1200{ }^{\circ} \mathrm{C}$.]

houve diferença estatisticamente significante nesses valores (teste $t$, valor $\mathrm{p}>0,05$ ) para todas as temperaturas de queima. Os menores valores de absorção de água das amostras D10 $(0,2 \%)$ e D20 $(0,0 \%)$ foram inferiores ao menor valor de absorção de água $(0,5 \%)$ da amostra de referência (teste $\mathrm{t}$, valor $\mathrm{p}<0,05)$, indicando que o uso do diopsídio além de reduzir a temperatura de queima possibilita obter menores valores de absorção de água. A norma brasileira para aparelhos sanitários (ABNT NBR 15097-1 [17]) preconiza valores de absorção de água inferiores a $0,5 \%$ para aplicação de cerâmicas como grés sanitário. Assim, verificou-se que a massa de referência se situou no limiar da norma, após queima a $1200{ }^{\circ} \mathrm{C}$, enquanto as amostras contendo 10 e $20 \%$ de diopsídio em substituição ao feldspato apresentaram valores abaixo da norma de forma mais segura e após queima a $1160{ }^{\circ} \mathrm{C}$.

Os módulos de ruptura à flexão para as amostras analisadas encontram-se expostos na Fig. 8. Todos os corpos apresentaram valores de resistência maior ou igual a $35 \mathrm{MPa}$, tendo a amostra de referência apresentado um valor máximo de $41 \mathrm{MPa}$, após queima a $1200{ }^{\circ} \mathrm{C}$. As amostras D6, D10 e D20 apresentaram valores de 
resistência superiores ao da amostra de referência (teste $\mathrm{t}$, valor $\mathrm{p}<0,05)$, considerando as mesmas temperaturas de queima, o que foi relacionado à maior taxa de retração dessas amostras e sua maior densificação comparativamente à amostra de referência. Nesse sentido, a formulação padrão, M0, necessita ser sinterizada em temperatura mais elevada para atingir performance mecânica similar à das amostras com a incorporação de diopsídio, conforme pode ser observado ao comparar o módulo de ruptura à flexão da M0 a $1200{ }^{\circ} \mathrm{C}$ que é de $41 \mathrm{MPa}$ ao das amostras contendo diopsídio após queima a $1160{ }^{\circ} \mathrm{C}$ : D6, $46 \mathrm{MPa}$; D10, $48 \mathrm{MPa}$; e D20, $54 \mathrm{MPa}$. Nesse cenário tem-se que é possível a redução da temperatura de queima quando do uso do diopsídio em detrimento do feldspato, reduzindo custos energéticos, mas mantendo-se níveis de resistência superiores ao da formulação convencional. De uma forma geral, a literatura reporta que a utilização do diopsídio em substituição parcial ao feldspato, em cerâmicas triaxiais, diminui a temperatura de sinterização [3] e aumenta a resistência à flexão [3, 4, 7], vindo ao encontro dos dados obtidos nesta pesquisa.

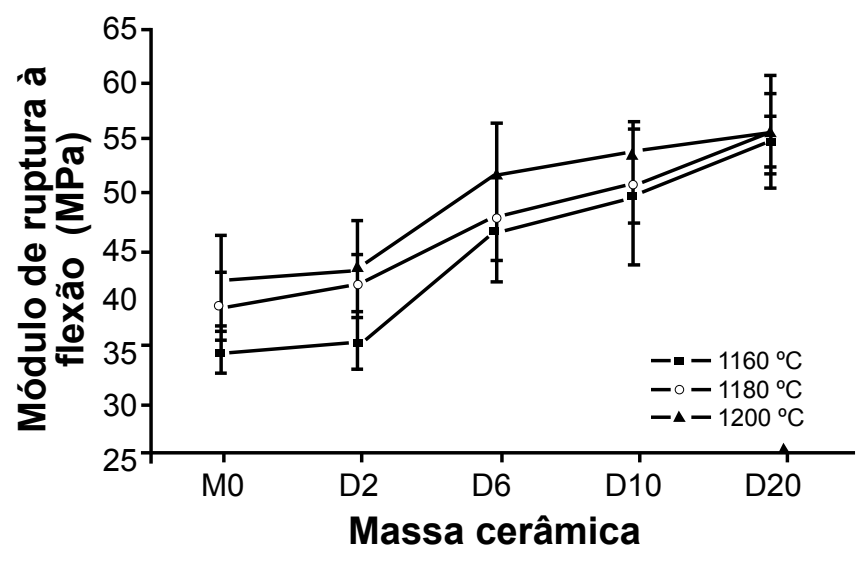

Figura 8: Tensão de ruptura à flexão dos corpos em função da substituição parcial do feldspato pelo diopsídio nas temperaturas de sinterização de 1160,1180 e $1200{ }^{\circ} \mathrm{C}$.

[Figure 8: Flexural rupture strength as a function of the partial substitution of feldspar by diopside at the sintering temperatures of 1160,1180 , and $1200{ }^{\circ} \mathrm{C}$.]

Neste momento é interessante destacar que a absorção de água e porosidade aparente da amostra D6 após queima a $1160{ }^{\circ} \mathrm{C}$ foi superior (teste $\mathrm{t}$, valor $\mathrm{p}<0,05$ ) ao da amostra de referência após queima a $1200{ }^{\circ} \mathrm{C}$, o que indicaria que a resistência dessa amostra D6 fosse menor que a da referência (M0), após queima a $1200{ }^{\circ} \mathrm{C}$. No entanto, isso não foi observado e pode estar relacionado à microestrutura (Figs. 4 e 5) do corpo cerâmico obtido contendo diopsídio. Este corpo apresentou como fases cristalinas mulita, quartzo, cristobalita e também anortita. Deste modo, o maior teor de fases cristalinas que contribuem para a resistência do material, como a mulita e a anortita, pode ser o responsável pela maior resistência da amostra D6, mesmo com maior porosidade, bem como dos elevados valores de resistência obtidos para as amostras D10 e D20 após queima a $1160{ }^{\circ} \mathrm{C}$. Uma das principais e mais antigas teorias acerca da resistência das porcelanas é a hipótese da mulita, na qual a resistência é dependente da estrutura interconectada, intertravada, formada pelas agulhas de mulita no meio da fase vítrea das porcelanas [35]. No entanto, outros fenômenos também podem contribuir para o aumento da resistência desses materiais, que são o reforço da matriz e o reforço por dispersão de partículas [35]. Na hipótese do reforço da matriz, a diferença nos coeficientes de expansão térmica entre a matriz e as demais fases presentes no material, sejam partículas dispersas ou fases cristalinas formadas durante a queima, provoca esforços de compressão na matriz, fase vítrea do material [35]. Esse esforço de compressão induzido durante o resfriamento do sistema contribui, segundo a teoria, para aumentar a resistência da porcelana. Nesse sentido, o aumento de resistência observado neste trabalho para as composições contendo diopsídio pode estar relacionado ao fenômeno/mecanismo de reforço de matriz. Nos materiais contendo diopsídio houve o desenvolvimento de anortita, com partículas da ordem de micrômetro e submicrômetro. A anortita apresenta um coeficiente de expansão térmica superior ao da mulita, da ordem de $10-15.10^{-6}{ }^{\circ} \mathrm{C}^{-1}[36,37]$, o que faz com que ocorra o desenvolvimento de um elevado campo de tensões no material, em virtude da diferença no coeficiente de expansão térmica desta fase e da fase vítrea que compõe a matriz do material. Isso, associado ao fato das partículas de anortita serem relativamente de pequenas dimensões e em elevada quantidade (Fig. 5), possibilita que haja um pré-tensionamento na matriz (prestress state), com a componente de compressão possibilitando o aumento da resistência do corpo, sem que haja excessivo descolamento das partículas de anortita da matriz e o desenvolvimento de trincas periféricas que, em elevada quantidade, poderia comprometer a resistência do material. Outros estudos [38-40] também observaram comportamento similar de aumento da resistência quando da adição do diopsídio em substituição ao feldspato nas formulações de porcelanas convencionais ou quando da produção de porcelanas denominadas 'porcelanas de anortita'. Nesses estudos, o aumento da resistência foi atribuído ao aumento da quantidade de fase cristalina no sistema, da maior relação quantidade de fase cristalina/quantidade de fase vítrea, e/ ou ao menor tamanho de poros nos sistemas estudados. No entanto, acredita-se que não se trata apenas de um aumento da fase cristalina e uma contribuição do fenômeno de reforço por dispersão de partículas, mas que houve uma contribuição significativa do efeito de diferença de coeficientes de expansão térmica e que esta contribuição só se faz presente de forma benéfica pelo pequeno tamanho das partículas da anortita formada e de sua uniformidade na microestrutura. No que tange à variação do módulo de ruptura à flexão das amostras contendo diopsídio em função da temperatura de queima, não se verificaram diferenças estatisticamente significativas nos valores de resistência nas amostras D6, D10 e D20 ao se aumentar a temperatura de queima (teste $\mathrm{t}$, valor $\mathrm{p}>0,05$ ). Isso era esperado 
para a amostra D10 e D20 que apresentaram valores de porosidade muito próximos ao se aumentar a temperatura de queima, no entanto não era esperado para a amostra D6, o que demonstrou que a microestrutura formada teve uma influência maior que a porosidade na determinação da resistência mecânica das peças produzidas. Assim, com o devido controle de microestrutura é possível obter peças com maiores valores de resistência em menores temperaturas de queima e utilizando menores teores de feldspato.

\section{CONCLUSÕES}

Este trabalho teve como objetivo avaliar o efeito da substituição parcial do feldspato pelo diopsídio em formulações para uso na fabricação de grés sanitário. As características reológicas de velocidade de deposição, tempo de secagem, relação $\alpha$ e de destacamento das formulações avaliadas não foram prejudicadas quando da substituição parcial do feldspato pelo diopsídio em até $20 \%$ na massa cerâmica. O uso do diopsídio conduziu ao desenvolvimento de uma microestrutura diferente de uma massa cerâmica triaxial tradicional, com a formação de anortita nas peças cerâmicas, como também possibilitou reduzir a temperatura de máxima taxa de retração/ densificação, comparativamente a uma massa comercial usada na produção de grés sanitário. Os corpos produzidos com formulações contendo diopsídio apresentaram maiores valores de resistência à flexão e redução na absorção de água e porosidade aparente. $\mathrm{O}$ teor de diopsídio nas formulações influenciou no comportamento de densificação: massas com até $6 \%$ de diopsídio, em substituição ao feldspato, atingiram após queima a $1180{ }^{\circ} \mathrm{C}$ absorção de água e resistência mecânica semelhantes ao valores da formulação sem diopsídio queimada a $1200{ }^{\circ} \mathrm{C}$, enquanto que massas com teores de $10 \%$ e $20 \%$ de diopsídio, em substituição ao feldspato, requereram temperatura de queima de 1160 ${ }^{\circ} \mathrm{C}$ para se atingir absorção de água inferior a $0,5 \%$. Os resultados comprovaram a viabilidade da incorporação do diopsídio em formulações para grés sanitário, havendo redução da temperatura de queima e aumento da resistência do corpo queimado.

\section{AGRADECIMENTOS}

À indústria Luzarte Estrela Ltda. - Caruaru-PE, pelo fornecimento das argilas e diopsídio. À indústria Armil Mineração do Nordeste - Parelhas-RN, pelo fornecimento do feldspato e quartzo.

\section{REFERÊNCIAS}

[1] Q. Li, F. Liu, X. Zhang, H. Yang, X. Xue, X. Niu, J. Alloys Compd. 657 (2016) 152.

[2] A. Barba, E. Sánchez, C. Feliu, J. García, F. Ginés, V. Sanz, V. Beltrán, Materias primas para la fabricación de suportes de baldosas cerámicas, ITC, Espanha (1997) 290.
[3] S. Junlong, L. Changxia, Z. Xihua, N. Xiuying, Ceram. Int. 35 (2009) 1321.

[4] L. Kuzmickas, F.R.D. Andrade, G.A.J. Szabó, J.F.M. Motta, M. Cabral Jr, Cerâmica 59 (2013) 345.

[5] V.I. Vereshchagin, A.E. Abakumov, Glass Ceram. 55 (1998) 252.

[6] V.I. Vereshchagin, V.K. Men'shikova, A.E. Buruchenko, N.V. Mogilevskaya, Glass Ceram. 67 (2011) 343.

[7] G.M.Azarov, A.S. Vlasov, E.V. Maiorova, M.A. Oborina, Glass Ceram. 52 (1995) 216.

[8] J. Wu, K. Li, X. Xu, Y. Zhang, X. Xu, X. Lao, Int. J. Appl. Ceram. Tec. 14 (2017) 454.

[9] M. Cavac, F. Kara, Key Eng. Mater. 264 (2004) 1487.

[10] V.I. Vereshchagin, N. Mogilevskaya, D. Gorbachev, Glass Ceram. 69 (2013) 401.

[11] L.S. Bozadjiev, R.L. Bozadjiev, G.T. Georgiev, L.S. Doncheva, Am. Ceram. Soc. Bull. 85 (2006) 9101.

[12] P. Souza Santos, Ciência e tecnologia de argilas, $2^{\mathrm{a}}$ ed., Edgar Blücher, S. Paulo (1992).

[13] M. Link, S. Bragança, C. Bergmann, Cerâm. Ind. 18 (2013) 25.

[14] A.C. Morelli, J.B. Baldo, Cerâm. Ind. 9 (2004) 30.

[15] A. Bernasconi, N. Marinoni, A. Pavese, F. Francescon, K. Young, Ceram. Int. 40 (2014) 6389.

[16] K. Kim, K. Kim, J. Hwang, Ceram. Int. 41 (2015) 7097.

[17] ABNT NBR 15097-1, "Aparelhos sanitários de material cerâmico - parte 1: requisitos e métodos de ensaios”, Rio de Janeiro (2017).

[18] ABNT NBR 6225, "Materiais refratários conformados - determinação da variação linear dimensional permanente após aquecimento", Rio de Janeiro (2013).

[19] ABNT NBR 16661, "Materiais refratários densos conformados - determinação do volume aparente, volume aparente da parte sólida, densidade de massa aparente, densidade aparente da parte sólida, porosidade aparente e absorção", Rio de Janeiro (2017).

[20] ABNT NBR 13818, "Placas cerâmicas para revestimento - especificação e métodos de ensaios", Rio de Janeiro (1997).

[21] G. Lecomte-Nana, A. Mokrani, N. Tessier-Doyen, K. Boussois, H. Goure-Doubi, Ceram. Int. 39 (2013) 9047.

[22] M.P. Babisk, F.W.H. Vidal, W.S. Ribeiro, M.S. Aguiar, M.C.B. Gadioli, M.C.F. Vieira, Holos 6 (2012) 169.

[23] F.H. Norton, Introdução à tecnologia cerâmica, E. Blucher (1973).

[24] R.V. Gaines, H.C.W. Skinner, E.E. Foord, B. Mason, A. Rosenzweig, in: Dana's new mineralogy: the system of mineralogy of James Dwight Dana and Edward Salisbury Dana, $8^{\text {th }}$ ed., Wiley-Interscience (1997).

[25] C. Wu, Y. Ramaswamy, H. Zreiqat, Acta Biomater. 6 (2010) 2237.

[26] A. Kazemi, M. Abdellahi, A. Khajeh-Sharafabadi, A. Khandan, N. Ozada, Mater. Sci. Eng. C 71 (2017) 604.

[27] R.R. Menezes, G.A. Neves, H.C. Ferreira, Rev. Eletr. Mater. Proc. 9 (2014) 118.

[28] A.H. De Aza, X. Turrillas, M.A. Rodriguez, T. Duran, P. Pena, J. Eur. Ceram. Soc. 34 (2014) 1409. 
[29] É.P. Moraes, N.R.C.F. Machado, S.C. Pergher, Acta Sci.-Technol. 25 (2003) 63.

[30] S.J.G. Sousa, J.N.F. Holanda, Cerâmica 51 (2005) 70.

[31] L.F.B. Marino, A.O. Boschi, Cerâm. Ind. 3 (1998) 18.

[32] B.K. Ngun, H. Mohamad, K. Katsumata, K. Okada, Z.A. Ahmad, Appl. Clay Sci. 87 (2014) 97.

[33] C. Essakli, A. Ider, Int. J. Innov. Appl. Stud. 9 (2014) 115.

[34] F.A. Firat, E. Ercenk, S. Yilmaz, J. Ceram. Proc. Res. 13 (2012) 756.

[35] W.M. Carty, U. Senapati, J. Am. Ceram. Soc. 81
(1998) 3.

[36] G.L. Hovis, A. Medford, M. Conlon, A. Tether, A. Romanoski, Am. Mineral. 95 (2010) 1060.

[37] E. Robertson, in: Thermal properties of rocks, Geological Survey (1988) 88.

[38] Z.B. Ozturk, J. Ceram. Proc. Res. 17 (2016) 555.

[39] M.U. Taskiran, N. Demirkol, A. Capoglu, J. Eur. Ceram. Soc. 25 (2005) 293.

[40] W.P. Tai, K. Kimura, K. Jinnai, J. Eur. Ceram. Soc. 22 (2002) 463.

(Rec. 10/02/2018, Rev. 16/04/2018, 02/06/2018, Ac. 25/06/2018) 